\title{
Efektivitas metode guided discovery pada pembelajaran sains terhadap perkembangan kognitif anak usia 5-6 tahun
}

\author{
Vera Sholeha \\ Program Studi Pendidikan Guru Pendidikan Anak Usia Dini, FKIP, Universitas Sebelas Maret \\ Jalan Slamet Riyadi No. 449, Pajang, Kec. Laweyan, Kota Surakarta, Jawa Tengah 57146, Indonesia \\ Email: verasholeha@staff.uns.ac.id
}

\begin{abstract}
ARTICLE INFO
ABSTRACT

Article history:

Received: 14-8-2019;

Revised: 4-9-2019;

Accepted:4-9-2019

Keywords:

guided discovery method, cognitive domain, science learning, early childhood education

Penelitian ini bertujuan untuk meneliti efektivitas metode guided discovery dalam pembelajaran sains terhadap perkembangan kognitif anak usia 5-6 tahun. Jenis penelitian ini adalah kuasi eksperimen (quasi-experimental research). Subjek uji efektivitas pada kelas eksperimen sebanyak 22 peserta didik kelas B1 TK ABA Kembaran dan pada kelas kontrol sebanyak 23 peserta didik kelas B2 TK ABA Kembaran. Pengumpulan data menggunakan lembar observasi dan tes lisan peserta didik. Teknik analisis data menggunakan independent sample t-test dengan taraf signifikansi 0,05. Hasil penelitian menunjukkan bahwa dengan menggunakan metode guided discovery dalam pembelajaran sains, terdapat perbedaan yang signifikan pada domain kognitif aspek "mengingat" pada anak usia 5-6 tahun. Terdapat perbedaan hasil akhir antara kelas kontrol dan kelas eksperimen setelah guru menggunakan metode guided discovery dalam pembelajaran sains dengan $\mathrm{p}<0,05$ kemudian terjadi pula peningkatan yang signifikan dengan $\mathrm{p}=0,000$.
\end{abstract}

This study aimed to examine the effectiveness of the guided discovery method in science learning towards cognitive development in children aged 5-6 years. This type of research was quasi experimental research. The effectiveness test subjects in the experimental class were 22 students in class B1 TK ABA Kembaran and in the control class were 23 students in class B2 TK ABA Kembaran. Data collection used observation sheets and oral tests of students. Data analysis technique used independent sample t-test with a significance level of 0.05. The results showed that by using the guided discovery method in science learning, there were significant differences in the cognitive domain of "remembering" aspect of children aged 5-6 years. There were differences in the final results between the control class and the experimental class after the teacher used the guided discovery method in science learning with $p$ $<0.05$ then there was also a significant increase with $p=0.000$.

\section{PENDAHULUAN}

Pendidikan sebagai suatu upaya untuk mewujudkan sumber daya manusia yang berkualitas dan berdedikasi tinggi kepada bangsa dan negara memerlukan suatu pendukung yaitu kiat dalam meningkatkan mutu pendidikan. Keberhasilan pendidikan tidak lepas dari peranan guru di sekolah. Peningkatan mutu pendidikan diarahkan untuk meningkatkan kualitas manusia Indonesia seutuhnya melalui olah olah pikir (aspek kognisi), olah rasa (aspek afeksi) dan olah kinerja (aspek psikomotoris) (Chatib, 2012, p.8).

Undang-Undang Sistem Pendidikan Nasional Nomor 20 Tahun 2003 juga menjelaskan definisi dari pendidikan yaitu usaha sadar dan terencana untuk mewujudkan suasana belajar dan proses pembelajaran agar peserta didik secara aktif mengembangkan potensi dirinya untuk memiliki kekuatan spiritual keagamaan, pengendalian diri, kepribadian, kecerdasan akhlak mulia serta keterampilan yang diperlukan dirinya, masyarakat, bangsa dan negara.

Menurut definisi Undang-Undang Sistem Pendidikan Nasional tersebut, dengan jelas dikatakan bahwa tujuan pendidikan adalah agar peserta didik secara aktif mengembangkan potensi dirinya. Upaya 
Vera Sholeha

dalam mengembangkan potensi yang dimiliki peserta didik inilah yang menjadi kunci utama diselenggarakannya proses pendidikan. Kurikulum PAUD yang diterapkan mengandung aspek-aspek perkembangan yang harus dioptimalkan pada anak. Salah satu aspek penting yang harus dikembangkan adalah aspek kognitif. Aspek kognitif adalah aspek yang berhubungan dengan pikiran sadar anak (Santrock, 2007, p. 48; Setiawan, Fajaruddin, \& Andini, 2019). Pada aspek ini, terdapat beberapa lingkup perkembangan yang harus dikembangkan pada anak yaitu (1) pengetahuan umum dan sains; (2) konsep bentuk, warna, ukuran dan pola; (3) konsep bilangan, lambang bilangan dan huruf.

Sains sebagai salah satu lingkup perkembangan dari aspek kognitif merupakan alat pengungkap keberadaan dan rahasia alam raya dan isinya atau sebagai salah satu sarana mencapai tujuan hidup manusia sangat penting untuk dipahami dan dikuasai. Jackman, Beaver, \& Wyatt (2014, p.176) juga menegaskan kembali bahwa masa usia dini merupakan masa pembelajaran secara langsung atau learning by doing. Oleh karena itu, jalan terbaik untuk belajar sains adalah dengan melakukan penemuan sains. Hal ini juga sependapat dengan Biddle, Garcia-Nevarez, Henderson, \& ValeroKerrick (2013, p. 352) yang menjelaskan bahwa anak usia dini mampu mempelajari sains apabila pembelajaran dilakukan secara nyata (langsung) dan menarik.

Essa (2012, p. 293) mengungkapkan sains untuk anak usia dini adalah sebuah usaha alami untuk anak yang memiliki karakteristik untuk selalu mengeksplorasi dunianya, mengajukan pertanyaanpertanyaan, memiliki rasa keingintahuan yang tinggi, mengamati, menyentuh dan merasakan sesuatu yang baru baginya. Morrison (2012, p. 307) mengungkapkan bahwa pembelajaran sains untuk anak usia dini membantu anak untuk memecahkan masalah. Lebih dari itu, Brenneman (2014, p. 1) mengungkapkan bahwa pengalaman belajar sains mendorong perkembangan bahasa dan keaksaraan, dan juga terkait dengan kemampuan belajar matematika dan kemampuan fungsi eksekutif anak. Sains juga dapat mendukung pembelajaran anak-anak dan kesiapan sekolah.

Penerapan pembelajaran sains pada anak usia dini, memerlukan metode pembelajaran yang tepat. Metode harus menunjang pencapaian tujuan pembelajaran. Berbicara mengenai proses pembelajaran di sekolah sebenarnya telah banyak usaha yang dilakukan oleh berbagai pihak, khususnya dalam penerapan metode pembelajaran untuk mencapai tujuan pembelajaran. Metode yang dianggap baik oleh pakar pendidikan saat ini adalah metode pembelajaran yang berpusat pada anak dan bukan yang berpusat pada aktivitas guru.

Proses pembelajaran sains di PAUD saat ini masih terkurung dalam paradigma lama yang menganggap siswa sebagai "gelas kosong" yang siap diisi dengan pengetahuan apapun. Pelaksanaan pembelajaran sains masih didominasi oleh metode konvensional (ceramah) dan selama ini para pendidik hanya berupaya mengembangkan dan menguji daya ingat siswa, sedangkan kemampuan berpikir rasional dan kreatif siswa kurang dikembangkan. Pengembangan kemampuan berpikir siswa seperti berpikir kritis dan kreatif terhambat sehingga yang berkembang hanya kemampuan mengingat. Para pendidik lebih menekankan pengembangan otak anak sebagai organ perekam daripada organ berpikir.

Peran pendidik dalam pembelajaran sains sebaiknya menerapkan prinsip dari John Dewey yaitu learning by doing. Anak belajar secara langsung melalui pengalaman-pengalaman belajar, sehingga pembelajaran lebih bermakna dan anak dapat menangkap pembelajaran dengan mudah. Salah satu metode pembelajaran yang melibatkan aktivitas langsung oleh anak adalah metode guided discovery (penemuan terbimbing).

Metode guided discovery adalah metode dimana guru memberikan bimbingan dan petunjuk kepada peserta didik dalam belajar dan menemukan suatu konsep (Carin \& Sund, 1970, p. 94). Hal ini sejalan dengan apa yang diungkapkan oleh Cagne (Hamalik, 2008, p. 188) metode guided discovery dilakukan oleh guru dan peserta didik. Discovery dilakukan oleh peserta didik, sedangkan guru berperan sebagai pembimbing peserta didik dalam melakukan penemuan. Metode ini mencoba membantu peserta didik agar peserta didik belajar untuk belajar. Artinya bahwa metode guided discovery membantu peserta didik memperoleh pengetahuan untuk diri mereka sendiri karena peserta didik telah menemukannya sendiri.

Carin \& Sund (1970, p. 94) menjelaskan bahwa metode guided discovery tidak terbatas untuk menemukan sesuatu yang sama sekali baru untuk dunia, seperti penemuan baru (televisi) atau teori, tetapi merupakan masalah internal menyusun ulang data sehingga siswa bisa melampaui data untuk membentuk konsep- konsep baru untuk mereka. Guided discovery melibatkan penemuan makna, organisasi dan struktur ide. Robert Karplus dan Herbert Their dari studi sains kurikulum pendidikan 
(SCIS), menggambarkan aspek ini adalah penemuan dengan cara "penemuan" merupakan pengakuan antara ide dan observasi, atau antara dua ide, atau antara dua observasi (Carin \& Sund, 1970, p. 94).

Dalam metode pembelajaran guided discovery penyajian masalah, pertanyaan dan peralatan yang diperlukan siswa disiapkan oleh guru. Masalah dan pertanyaan ini yang mendorong siswa melakukan penyelidikan/pencarian untuk menemukan jawabannya yang berupa konsep dan prinsip-prinsip yang masih baru. Guided discovery memberikan hal-hal yang baru yang sebelumnya belum pernah dialami dan dilakukan siswa, sehingga siswa akan memiliki pengalaman yang dapat tersimpan dalam ingatannya dengan baik, tahan lama dan berkesan.

Tujuan dari guided discovery bagi anak usia dini adalah agar anak-anak dapat membuat hubungan dan membangun konsep melalui interaksi dengan benda dan manusia (Siddiq, 2008, p. 92). Guru merencanakan pengalaman bagi anak agar mereka dapat menemukan sesuatu. Guided discovery lebih memusatkan perhatian pada proses belajar anak bukan pada hasil yang dicapainya. Peranan anak adalah membangun pengetahuan sendiri, membuat pilihan dan keputusan, serta melakukan percobaan sederhana. Peranan guru adalah untuk menyediakan alat dan informasi yang diperlukan, yang dapat mendorong kemajuan belajar anak melalui pengembangan kemampuan yang berkaitan.

Berdasarkan observasi yang dilakukan di TK ABA Kembaran Kasihan Bantul, ternyata pembelajaran sains dilaksanakan hanya dengan metode ceramah dan diskusi. Model pembelajaran yang digunakan masih klasikal, keterlibatan guru selama pembelajaran masih dominan dan siswa tidak terlibat secara langsung selama pembelajaran. Siswa cenderung selalu menerima apa saja yang diberikan guru, tidak termotivasi untuk turut aktif dalam pembelajaran. Guru juga masih mengandalkan LKA (Lembar Kerja Anak) yang disediakan oleh sekolah yang hanya mengukur daya ingat anak saja. Respon siswa terhadap pembelajaran cenderung rendah. Keadaan ini mengakibatkan siswa kehilangan daya kritis dan daya kreatifnya untuk menghubungkan antara pengetahuan uang didapatkannya dengan kehidupan nyata. Orientasi guru dalam melaksanakan pembelajaran lebih terfokus pada pencapaian target yang tinggi dalam penyampaian materi sehingga seringkali mengabaikan proses pemberdayaan aspek afektif dan psikomotorik.

Untuk itu, maka diperlukan pemilihan metode pembelajaran yang tepat. Metode pembelajaran yang mampu mengubah paradigma pembelajaran dari siswa sebagai objek/sasaran pembelajaran menjadi subjek/pelaku dari proses pembelajaran. Metode pembelajaran tersebut harus mampu mengikutsertakan semua siswa untuk mendapatkan peran, mampu mengembangkan kemampuan dasar siswa dan sikap positif siswa sehingga proses belajar mengajar menjadi lebih menarik, menantang, menyenangkan dan mengaktifkan semua aspek dari dalam diri siswa.

Pembelajaran dengan metode guided discovery di TK ABA Kembaran Kasihan Bantul diharapkan memberikan hasil, karena metode guided discovery yang melibatkan anak sebagai pembelajar langsung diharapkan berhasil mengoptimalkan pemahaman sains anak serta dapat menumbuhkembangkan potensi berpikir kritis pada anak dalam belajar. Untuk itulah peneliti bermaksud meneliti tentang efektivitas penerapan metode guided discovery dalam pengenalan sains sederhana dan peningkatan motivasi belajar anak usia 5-6 tahun.

\section{METODE}

Jenis penelitian ini adalah kuasi eksperimen (Quasi-Experimental Research). Kuasi eksperimen merupakan sebuah eksperimen semu dalam sebuah penelitian karena melibatkan penggunaan kelompok subjek utuh dalam eksperimen yang secara alami sudah terbentuk dalam kelas. Digunakannya kuasi eksperimen ini karena dalam bidang pendidikan seringkali sulit melakukan eksperimen secara murni karena dalam hal ini subjek (peserta didik) bukanlah sesuatu yang dapat dipindah, diperlakukan dan diatur secara tepat/pas sebagaimana pada penelitian murni.

Penelitian ini dilaksanakan di TK ABA Kembaran Kasihan Bantul. Subjek uji efektivitas pada kelas eksperimen sebanyak 22 peserta didik kelas B1 dan pada kelas kontrol sebanyak 23 peserta didik kelas B2. Penelitian ini diawali dengan kegiatan prasurvey, sehingga diketahui permasalahan secara objektif tentang proses pembelajaran sains dan kemampuan domain kognitif peserta didik. Teknik pengumpulan data yang dilakukan dalam penelitian ini adalah melalui tes dan non tes. Teknik tes yang digunakan berupa pretest dan posttest. Pretest dilakukan untuk mengukur homogenitas kemampuan awal/dasar, yang harus tidak berbeda antara kelas eksperimen dan kelas kontrol. Teknik non tes yang digunakan dalam penelitian ini adalah observasi dan wawancara. Observasi dilakukan untuk mengamati proses pembelajaran sains anak dan mengetahui tingkatan domain kognitif anak. Sedangkan wawancara 
Vera Sholeha

digunakan untuk memperkuat hasil observasi. Subjek wawancara adalah guru dan anak.

Pengujian hipotesis menggunakan statistik parametrik dimana data dinyatakan normal dan homogen. Kemudian untuk mengetahui adakah perbedaan dua perlakuan dalam penerapan metode guided discovery terhadap pengenalan sains sederhana dan peningkatan domain kognitif anak dengan uji-t. Data yang sudah terkumpul ini kemudian diuji dengan menggunakan bantuan SPSS 20 for windows.

\section{HASIL DAN PEMBAHASAN}

\section{Hasil}

Untuk mengetahui ada tidaknya peningkatan perkembangan kognitif peserta didik dilakukan dengan uji-t berpasangan (paired sample t-test), namun sebelumnya dilakukan uji prasyarat terlebih dahulu yaitu uji normalitas dan uji homogenitas. Pengujian normalitas berdasarkan pada hipotesis berikut: Ho yaitu sampel berasal dari populasi berdistribusi normal, Ha yaitu sampel tidak berasal dari populasi berdistribusi normal. Sedangkan pengujian homogenitas berdasarkan pada hipotesis berikut: Ho, yaitu varian pada tiap kelompok sama (homogen), dan Ha merupakan varian pada tiap kelompok tidak sama (tidak homogen). Normalitas dan homogenitas terpenuhi atau Ho diterima dan Ha ditolak jika nilai signifikansi lebih dari 0.05 . Data hasil uji normalitas dan uji homogenitas dapat dilihat pada Tabel 1 dan Tabel 2.

Tabel 1. Data Hasil Uji Normalitas Perkembangan Kognitif Peserta Didik

\begin{tabular}{lllllll}
\hline \multirow{2}{*}{ Data } & \multicolumn{3}{c}{ Nilai sig (p) } & \multirow{2}{*}{ Kondisi } & \multirow{2}{*}{ Ket } \\
\cline { 2 - 5 } & \multicolumn{2}{c}{ KK } & \multicolumn{2}{c}{ KE } & & Normal \\
\hline Aspek & 0,09 & 0,15 & p & & \\
Mengingat & 3 & 2 & 0,05 & & \\
\hline
\end{tabular}

Berdasarkan Tabel 1, dapat dilihat bahwa nilai signifikansi perkembangan kognitif peserta didik lebih besar dari 0,05, sehingga Ho diterima atau data berdistribusi normal.

Tabel 2. Data Hasil Uji Homogenitas Perkembangan Kognitif Peserta Didik

\begin{tabular}{llll}
\hline Data & Nilai sig $(\mathrm{p})$ & Kondisi & Ket \\
\hline Aspek Mengingat & 0,101 & $\mathrm{p}>0,05$ & Homogen \\
\hline
\end{tabular}

Berdasarkan Tabel 2, dapat dilihat bahwa nilai signifikansi perkembangan kognitif peserta didik lebih besar dari 0,05 sehingga Ho diterima. Dengan demikian, data tersebut memiliki varians yang sama atau homogen. Setelah uji prasyarat terpenuhi, langkah selanjutnya adalah menentukan peningkatan perkembangan kognitif peserta didik dengan menggunakan uji-t berpasangan (paired sample t-test). Uji-t berpasangan ini untuk menguji hipotesis penelitian berikut: Ho yaitu tidak terdapat peningkatan yang signifikan perkembangan kognitif peserta didik aspek mengingat yang gurunya menerapkan metode guided discovery dalam pembelajaran sains. Ha yaitu Terdapat peningkatan yang signifikan perkembangan kognitif peserta didik aspek mengingat yang gurunya menerapkan metode guided discovery dalam pembelajaran sains.

Pengujian hipotesis dilakukan pada data perkembangan kognitif peserta didik aspek mengingat di kelas kontrol dan eksperimen. Data hasil uji-t berpasangan untuk perkembangan kognitif peserta didik dapat dilihat pada Tabel 3 dan Tabel 4.

Tabel 3. Data Hasil Uji Beda Perkembangan Kognitif Peserta Didik Pada Kelas Kontrol

\begin{tabular}{lllllll}
\hline Aspek & Data & Mean & N & Sig.(p) & Analisis & Ket \\
\hline \multirow{2}{*}{ Mengingat } & Pre test & 12.9565 & & & & \\
& $\begin{array}{l}\text { Post test } \\
\text { Post test }\end{array}$ & 13.0870 & 23 & 0,186 & $\mathrm{p}>0,05$ & Ho diterima \\
\hline
\end{tabular}

Berdasarkan tabel 3, dapat diketahui sebagai berikut; nilai signifikansi aspek mengingat adalah 0,186. Angka tersebut menunjukkan nilai signifikansi lebih dari 0,05 sehingga Ho diterima dan Ha ditolak. Jadi, tidak terdapat peningkatan yang signifikan perkembangan kognitif peserta didik pada aspek mengingat yang gurunya menerapkan metode guided discovery. 
Tabel 4. Data Hasil Uji Beda Perkembangan Kognitif Peserta Didik Pada Kelas Eksperimen

\begin{tabular}{clccccc}
\hline Aspek & Data & Mean & N & Sig.(p) & Analisis & Ket \\
\hline \multirow{2}{*}{ Mengingat } & $\begin{array}{l}\text { Pre test } \\
\text { Post test } \\
\text { Post test }\end{array}$ & 13,4545 & 22 & 0,000 & $\mathrm{p}<0,05$ & Ho ditolak \\
\hline
\end{tabular}

Berdasarkan tabel 4, dapat diketahui bahwa nilai signifikansi adalah 0,000 atau kurang dari 0,05 sehingga Ho ditolak dan Ha diterima. Jadi, terdapat peningkatan yang signifikan perkembangan kognitif peserta didik aspek mengingat yang gurunya menerapkan metode guided discovery dalam pembelajaran sains.

Untuk mengetahui ada tidaknya perbedaan perkembangan kognitif kelas control dan kelas eksperimen dilakukan dengan uji-t independen (independent sample t-test). Uji-t independen untuk menguji hipotesis penelitian berikut: Ho adalah tidak terdapat perbedaan perkembangan kognitif peserta didik aspek mengingat yang gurunya menerapkan metode guided discovery dalam pembelajaran sains. $\mathrm{Ha}$ adalah Terdapat perbedaan perkembangan kognitif peserta didik aspek mengingat yang gurunya menerapkan metode guided discovery dalam pembelajaran sains.

Pengujian hipotesis dilakukan pada perkembangan kognitif awal dan akhir kelas kontrol dan kelas eksperimen. Rangkuman data hasil perhitungan uji-t independen untuk perkembangan kognitif peserta didik pada tabel 5 .

Tabel 5. Uji-t Independen Perkembangan Kognitif Kelas Kontrol dan Kelas Eksperimen

\begin{tabular}{rlllll}
\hline Data & Kelas & Rata- rata Skor & N & Sig. $(\mathrm{p})$ & Ket \\
\hline \multirow{2}{*}{ Mengingat } & KK & 14,3043 & 23 & \multirow{2}{*}{0,000} & \multirow{2}{*}{ Ho ditolak } \\
& KE & 19,7727 & 22 & & \\
\hline
\end{tabular}

Berdasarkan tabel diketahui bahwa nilai signifikansi untuk perkembangan kognitif peserta didik aspek mengingat adalah 0,000 atau kurang dari 0,05 sehingga Ho ditolak dan Ha diterima. Jadi terdapat perbedaan perkembangan kognitif peserta didik pada aspek mengingat yang gurunya menerapkan dan tidak menerapkan metode guided discovery dalam pembelajaran sains.

\section{Pembahasan}

Uji efektivitas dilakukan untuk mengetahui apakah penerapan metode guided discovery kepada peserta didik usia 5-6 tahun dapat meningkatkan perkembangan kognitif mereka. Pada uji efektivitas, indikator penilaian disesuaikan dengan dimensi proses kognitif menurut Revisi Taksonomi Bloom yang terdiri dari 6 kategori yaitu remember, understand, apply, analyze, evaluate, dan create (Krathwohl \& Anderson, 2009, p 5). Pada enam kategori dimensi proses kognitif tersebut, tujuan (sasaran) yang dilakukan dalam penelitian ini sebatas pada kategori remember. Hal ini didasarkan atas pertimbangan bahwa kemampuan kognitif anak mempunyai tahap-tahap yang harus diperhatikan dan tidak semua kategori dimensi proses kognitif diukur karena hal tersebut disesuaikan dengan tahap perkembangan anak.

Penelitian ini bertujuan untuk mengetahui apakah penerapan metode guided discovery dapat memudahkan guru-guru PAUD dalam menerapkan pembelajaran sains serta dapat meningkatkan perkembangan kognitif peserta didik. Peneliti menggunakan dua kelas yaitu satu kelas kontrol yang proses pembelajarannya dikembangkan oleh guru sendiri (ceramah dan tanya jawab), sedangkan kelas lainnya yaitu kelas eksperimen yang proses pembelajarannya menerapkan metode guided discovery.

Hasil post-test perkembangan kognitif peserta didik kelas eksperimen dan kelas kontrol, menunjukkan nilai signifikansi 0,000 atau kurang dari 0,05 sehingga dapat disimpulkan adanya perbedaan perkembangan kognitif peserta didik pada aspek mengingat yang gurunya menerapkan dan tidak menerapkan metode guided discovery pada pembelajaran sains. Hal ini sesuai dengan pendapat Carin \& Sund (1970, p.94) yang menyatakan bahwa metode guided discovery adalah metode dimana guru memberikan bimbingan dan petunjuk kepada peserta didik dalam belajar dan menemukan suatu konsep. Discovery dilakukan oleh peserta didik, sedangkan guru berperan sebagai pembimbing dalam melakukan penemuan. Metode ini mencoba membantu peserta didik agar peserta didik dapat belajar untuk belajar. Artinya bahwa metode guided discovery membantu peserta didik memperoleh pengetahuan untuk diri mereka sendiri karena mereka telah menemukannya sendiri. Dengan hal ini, maka akan memudahkan peserta didik untuk membangun pengetahuan mereka, sehingga dapat 
Vera Sholeha

meningkatkan aspek perkembangan kognitifnya.

\section{SIMPULAN}

Metode guided discovery terbukti efektif untuk meningkatkan perkembangan kognitif peserta didik. Hasil perhitungan paired sample t-test menunjukkan bahwa terdapat perbedaan yang signifikan terhadap peningkatan perkembangan kognitif peserta didik pada aspek mengingat pada kelas eksperimen yang gurunya menerapkan metode guided discovery dalam pembelajaran sains. Selanjutnya, berdasarkan hasil perhitungan independent sample t-test menunjukkan bahwa terdapat perbedaan yang signifikan terhadap perkembangan kognitif peserta didik pada aspek mengingat pada kelas eksperimen yang gurunya menerapkan metode guided discovery dengan kelas kontrol yang proses pembelajarannya dikembangkan oleh guru sendiri (metode ceramah dan tanya jawab).

\section{UCAPAN TERIMA KASIH}

Puji syukur kehadirat Allah SWT atas limpahan rahmat dan karunia-Nya, sehingga penulis dapat menyelesaikan artikel dengan judul: Efektivitas Metode Guided discovery Pada Pembelajaran Sains Terhadap Perkembangan Kognitif Anak Usia 5-6 Tahun. Penghargaan dan terima kasih penulis berikan kepada Ibu Dr. Siti Wahyuningsih yang telah memberikan bimbingan dan masukan dalam rangka perbaikan penelitian ini. Serta ucapan terima kasih kepada Ibu Dra. Sri Kartininingsih, S. Pd selaku Kepala Sekolah, para guru, dan karyawan di TK ABA Kembaran yang telah membantu dan bersedia menjadi sumber informasi bagi penelitian kami. Akhir kata penulis menyadari bahwa dalam penulisan artikel ini masih jauh dari kesempurnaan. Karena itu, penulis memohon saran dan kritik yang sifatnya membangun dan semoga bermanfaat bagi kita semua. Aamiin.

\section{DAFTAR PUSTAKA}

Biddle, K. A. G., Garcia-Nevarez, A., Henderson, W. J. R., \& Valero-Kerrick, A. (2013). Early childhood education: Becoming a professional. Sage.

Brenneman, K. (2014). Science in the early years. Education Commission of the States Progress of Education Reform, 15(2), 1-6.

Carin, A. A., \& Sund, R. B. (1970). Teaching science through discovery. Columbus, OH: Charles E.

Chatib, M. (2012). Sekolah anak-anak juara: berbasis kecerdasan jamak dan pendidikan berkeadilan. Kaifa.

Essa, E. L. (2012). Introduction to early childhood education. Cengage Learning.

Hamalik, O. (2003). Proses belajar mengajar. Jakarta: PT Bumi Aksara.

Jackman, H., Beaver, N., \& Wyatt, S. (2014). Early education curriculum: A child's connection to the world. Cengage Learning.

Krathwohl, D. R., \& Anderson, L. W. (2009). A taxonomy for learning, teaching, and assessing: A revision of Bloom's taxonomy of educational objectives. Longman.

Morrison, G. S. (2012). Dasar-dasar pendidikan anak usia dini (PAUD). Jakarta: Indeks.

Santrock, J. (2007). Perkembangan anak (Alih bahasa: Mila Rachmawati dan Anna Kuswanti). Jakarta: Erlangga.

Setiawan, A., Fajaruddin, S., \& Andini, D. (2019). Development an honesty and discipline assessment instrument in the integrated thematic learning at elementary school. Jurnal Prima Edukasia, 7(1), 9-19. doi:https://doi.org/10.21831/jpe.v7i1.23117

Siddiq, M. D. (2008). Pengembangan bahan pembelajaran SD. Jakarta: Direktorat Jenderal Pendidikan Tinggi, Depdiknas.

Undang-Undang-undang Republik Indonesia Nomor 20 Tahun 2003 tentang Sistem Pendidikan Nasional. 